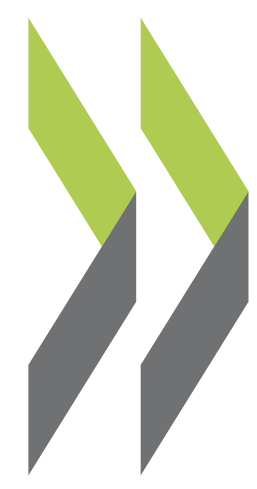

OECD Economics Department Working Papers No. 435

Sources of Inflation Persistence in the Euro Area

\section{Boris Cournède,}

Alexandra Janovskaia, Paul van den Noord 
Organisation de Coopération et de Développement Economiques

Organisation for Economic Co-operation and Development

20-Jul-2005

ECONOMICS DEPARTMENT

English - Or. English

SOURCES OF INFLATION PERSISTENCE IN THE EURO AREA

ECONOMICS DEPARTMENT WORKING PAPER, No. 435

by Boris Cournède, Alexandra Janovskaia and Paul van den Noord

All Economics Department Working Papers are now available through OECD's Internet Web site at http://www.oecd.org/eco/ 
TABLE OF CONTENTS

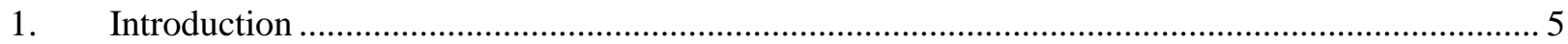

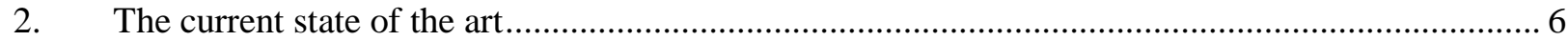

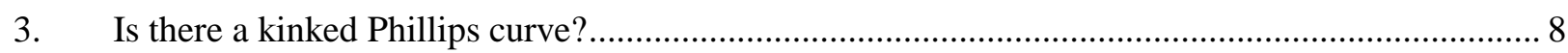

3.1 Identifying cross-regional differences in inflation responsiveness ......................................... 8

3.2 Relating differences in inflation responsiveness to structural policy settings .......................... 11

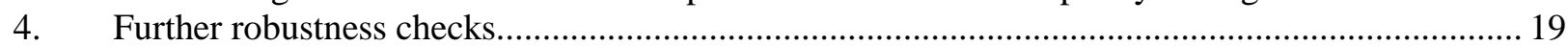

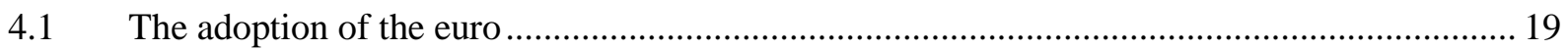

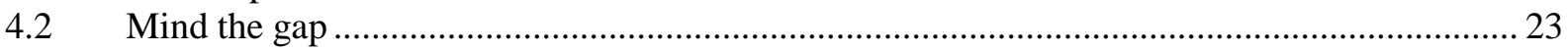

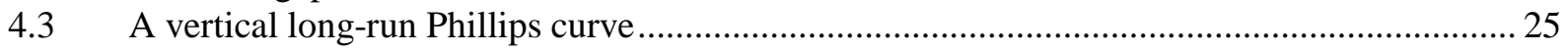

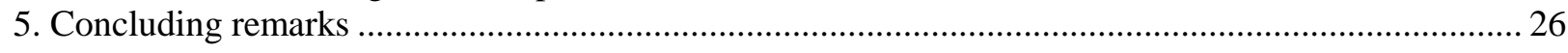

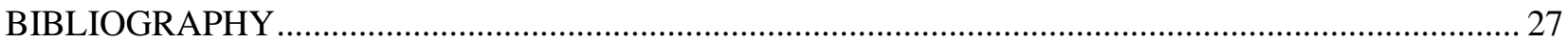

\section{Figures}

1. Inflation responsiveness to output

2. Average values for the three structural policy indicators (1985-2004)

\section{Tables}

1: Estimated price equation with country group-specific output gap coefficients

2: Structural policy indicators (beginning and end-of-period values)

3. Estimated price equations: baseline model

4. The impact of slack on inflation

5. Estimated price equations with pairs of structural policy indicators

6. Estimated price equations with concentration in wage setting and structural breaks

7. Estimated price equations with employment protection legislation and structural breaks

8. Estimated price equations with product market regulation and structural breaks

9. Estimated price equations with an alternative output gap measure

10. Equation with imposed unity on inflation expectations (past and future) 


\begin{abstract}
In recent years, inflation in the euro area has failed to decelerate decisively while cyclical slack built up in the economy. Is this phenomenon more than a peculiarity in recent data? Is it related to structural policy settings? Econometric analysis conducted on two decades of quarterly data covering 17 countries yields a yes on both counts. First, inflation is shown to respond significantly more weakly to cyclical slack in the euro area than in countries such as the United Kingdom, the United States or Canada. Secondly, this lack of responsiveness is found to be related in a statistically significant way to more rigid structural policy settings. The results pass a wide range of robustness checks.
\end{abstract}

This Working Paper relates to the 2005 OECD Economic Survey of the euro area (www.oecd.org/eco/surveys/euroarea).

JEL Codes: E31; E32; E52; E58.

Key words: inflation; inflation persistence; monetary policy; European Economic and Monetary Union

*****

\title{
Résumé
}

Au cours des dernières années, l'inflation ne s'est pas ralentie de manière sensible au sein de la zone euro alors même que l'écart de production y devenait de plus en plus négatif. Ce phénomène est-il plus profond qu'une bizarrerie des statistiques économiques récentes? Y a-t-il un lien avec les caractéristiques structurelles de la zone euro ? L'analyse économétrique de deux décennies de données trimestrielles pour dix-sept pays conduit à répondre oui à chacune de ces questions. Premièrement, il apparaît que, pour un même écart de production négatif, l'inflation ralentit moins dans la zone euro que dans des pays comme le Royaume-Uni, les États-Unis ou le Canada. Deuxièmement, il existe un lien statistiquement significatif entre ce manque de réactivité et une plus grande rigidité des politiques structurelles. La robustesse de ces résultats est confirmée par un large éventail de tests.

Ce Document de travail se rapporte à l'Etude économique de l'OCDE de la zone euro, 2005 (www.oecd.org/eco/etudes/zoneeuro).

JEL Codes : E31; E32; E52; E58.

Key words : l'inflation; la persistance de l'inflation; la politique monétaire, Union économique et monétaire

\section{Copyright OECD, 2005}

Application for permission to reproduce or translate all, or part of, this material should be made to: Head of Publications Service, OECD, 2 rue André Pascal, 75775 Paris Cedex 16, France. 


\section{ECO/WKP(2005)22}




\title{
SOURCES OF INFLATION PERSISTENCE IN THE EURO AREA
}

\author{
Boris Cournède, Alexandra Janovskaia and Paul van den Noord ${ }^{* *}$
}

\section{Introduction}

1. Since the inception of the single currency on 1 January 1999, inflation has mostly been slightly above the $2 \%$ limit of the ECB's operational definition of price stability. By most measures, including the HICP and the GDP deflator, inflation did not decline much even when activity fell unambiguously below potential with the onset of the 2001 downturn. This is in stark contrast with developments in other parts of the OECD - including the United States - where the inflation response to slack has been much more pronounced (Figure 1). A failure of prices to decelerate when slack builds up hampers monetary policy as it limits the scope for reducing interest rates in times of slack and thus reduces the euro area's resilience to adverse shocks. It also slows down the adjustment of real effective exchange rates within the euro area in the face of asymmetric shocks and hence contributes to persistent growth divergences. Identifying and addressing the causes of price inertia is therefore an important challenge for those in charge of managing the single currency, as emphasised inter alia by Issing (2004) and the European Commission (2003).

\section{Figure 1. Inflation responsiveness to output ${ }^{1}$} In per cent

Output gap (left-hand scale)

Euro area

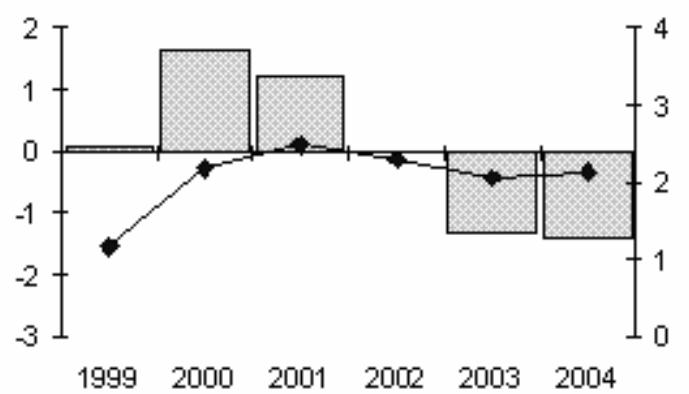

$\longrightarrow$ - Inflation (right-hand scale)

United States

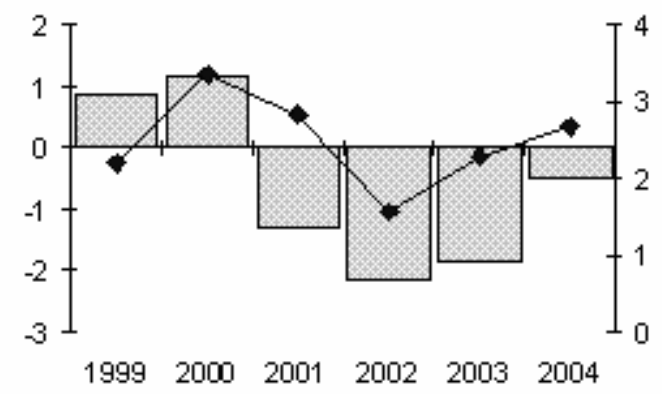

1. Inflation is gauged by the rate of change of the CPI in the United States and the HICP in the euro area. Source: OECD Economic Outlook No. 77 Database.

2. In this paper we present econometric analysis to examine to which extent the lack of inflation responsiveness in euro area countries may be related to structural policy settings. The approach is inspired by a wide strand of the economic literature looking at the responsiveness of prices to output conditions in

Boris Cournède and Paul van den Noord are economist and senior economist, respectively, in the Economics Department; email boris.cournède@oecd.org and paul.vandennoord@oecd.org. Alexandra Janovskaia (a.janovskaia-alumni@lse.ac.uk) has contributed to this paper as an intern in the Economics Department. An earlier draft of this paper was presented at the XVII Villa Mondragone International Economic Seminar on "Capitalism and Entrepreneurship Dynamics: Benchmarking Europe's Growth", CEIS - University of Rome "Tor Vergata", July 6th - 7th 2005.The authors are indebted to colleagues in the Department and participants at the Seminar for helpful comments. The views in this paper are the authors' and should not be attributed to the OECD or its member countries. 
low inflation environments e.g. Tobin (1972), Holden (1994, 2004), Akerlof, Dickens and Perry (1996, 2000) and Mourougane and Ibaragi (2004). In a fashion similar to the investigations by Honohan and Lane (2003, 2004), inflation is regressed on the output gap and a number of other variables for a panel of countries while time fixed effects capture common movements so as to focus on the effect of idiosyncratic changes in the explanatory variables. Moreover, akin to Nunziata and Bowdler (2005), the output gap is interacted with structural indicators so as to capture the effect of structural policies on the inflation response to the output gap. Unlike Nunziata and Bowdler (2005), however, the output gap has been separated in two variables which respectively cover its positive and negative values to account for asymmetries in the way institutional settings interact with the inflation process. While rigidities in product and factor markets are anticipated to fuel inflationary pressures when the economy is growing above potential, they are expected to weaken the extent to which prices decelerate at times of slack - i.e. they result in a "kinked" Philips curve.

3. The paper is structured as follows. Section 2 briefly reviews the theoretical and empirical literature on defining and estimating inflation persistence. Section 3 describes the methodology and the empirical results. Section 4 presents various robustness checks. Section 5 draws conclusions.

\section{The current state of the art}

4. The research on inflation responsiveness focuses on the role of output in inflation performance. In academic circles, this analysis is seen as being different from the issue of inflation persistence. Broadly speaking, inflation is described as persistent when it is primarily determined by its previous rate. Defining the concept technically is still a subject of academic debate. Probably the most straightforward definition of inflation persistence is that inflation is highly auto-correlated with its own lags (European Commission, 2003). Similarly, many authors define persistence as in Andrews and Chen (1994) by examining whether the sum of autoregressive coefficients is close to one. In technical terms, the test checks whether inflation can be described as a unit root process. Using this approach, Benati (2004) shows that euro area inflation is persistent in a statistically significant way at high confidence levels for the three price indices he examines (HICP, the private consumption deflator and the GDP deflator).

5. A related but thus far inconclusive way to look at inflation persistence is to compare the explanatory power of lagged inflation and a forward-looking supply-side indicator in a price equation usually called a New Keynesian Phillips Curve (NKPC). Implementing analysis of this nature on euro area data for the period 1970-97, McAdam and Willman (2004) conclude that their forward-looking composite supply-side measure has a significant effect on price developments. Using direct measures of inflation expectations, Adam and Padula (2003) and Paloviita (2004) find a strongly significant forward-looking component. However, after estimating various NKPCs on euro area data for 1971-98, Bardsen, et al. (2004) caution that slight changes in the estimation methodology can very quickly result in the forward-looking term being found not significant. This divergence of views is far from being specific to the euro area as the debate on fitting NKPCs on US inflation data has spawned a wide body of literature which remains largely inconclusive due to largely unresolved estimation difficulties (Henry and Pagan, 2004).

6. Another potential issue when defining inflation persistence by means of time-invariant coefficients drawn from single-country regressions is that they may not be robust to the occurrence of structural changes, in which case they lead to overestimating persistence (Perron, 1989). Judging it unrealistic to assume that changes in the macroeconomic framework such as modifications in the monetary policy regime do not affect the inflation process, Cogley and Sargent (2003); Levin and Piger (2003) and Benati (2004) have argued that structural breaks should be allowed in such regressions. This means that the coefficients are not fixed over time but can change. Estimating a single-country regression model of this nature, Marques (2004) finds a low level of persistence in the euro area and in the United States. Benati 
(2004) and Levin and Piger (2003) come to the same conclusion for several European countries but not for the euro area, which is absent from their data set. ${ }^{1}$ In contrast, the euro area evidence in favour of structural breaks and hence low persistence may be econometrically weak. O'Reilly and Whelan (2003) conclude that tests for structural breaks in the inflation process suffer from small-sample bias in the euro area. When this bias is corrected, they reckon that the hypothesis of no change cannot be rejected, which in turn implies strong persistence. On the other hand, this study does not take into account additional information about the timing of changes in the monetary policy regime and may therefore underestimate the probability of a break.

7. The ECB's Inflation Persistence Network (IPN) defines persistence as "the tendency of inflation to converge slowly (or sluggishly) towards its long run value" (Angeloni et al., 2004). One of the main empirical findings is that consumer price adjustment is half as frequent in the euro area as in the United States where retail prices change on average every two quarters. Secondly, the Eurosystem finds that implicit pricing contracts and strategic interactions among competing firms are the main sources of price stickiness for producer prices. Thirdly, the degree of inflation persistence increases with the level of aggregation and, finally, the most persistent sectors such as services drive the persistence of nation-wide indices (Angeloni et al., 2004). Yet, most of the studies conducted under the auspices of the IPN do not find much higher inflation persistence in the euro area than in the United States (Ciccarelli, 2004; Doosche and Everaert, 2004).

8. An important feature of the inflation process is its responsiveness to output developments - or a lack thereof - and this is the basis for the definition of persistence used in the present study. As mentioned above, this definition follows a wide strand of the economic literature looking at price inertia and the sacrifice ratio of monetary policy in low inflation environments e.g. Tobin (1972); Holden $(1994,2004)$; Akerlof, Dickens and Perry (1996, 2000); Mourougane and Ibaragi (2004). The definition of inflation persistence adopted in this paper can be made operational in a regression of inflation on its own lags and on the previous period's output gap, split in its negative and positive components. This amounts to estimating a Phillips curve that can be backward-looking, New Keynesian, sticky information-based à la Mankiw and Reis (2002) or hybrid but does not impose the constraint that inflation should respond symmetrically to cyclical slack and excess demand - i.e. it may be "kinked". In this definition, the higher the contribution of the autoregressive terms is relative to the negative output gap term, the more persistent inflation is.

9. If estimated for a single country, this regression runs into the numerous estimation difficulties that Henry and Pagan (2004) describe. However, for the purpose of documenting differences between countries, we circumvent these issues by implementing a pooled time series regression with period and country fixed effects. The methodology is largely inspired by the framework proposed by Honohan and Lane (2003, 2004) and Mayes and Viren (2002). Inflation is regressed on the output gap and a number of other variables for a panel of countries. As observed by Mehra (2004), controls must be included for supply shocks which otherwise obscure the effect of the output gap. This has been done by including import prices, trend labour productivity and indirect taxes. Time fixed effects capture common movements so as to focus on the effect of idiosyncratic changes in the explanatory variables.

1. A recurrent problem when examining longitudinal features of euro area data is that the period from January 1999 to the present is too short to estimate models with many parameters while longer samples aggregating pre-1999 national data are somewhat artificial. 


\section{Is there a kinked Phillips curve?}

\subsection{Identifying cross-regional differences in inflation responsiveness}

10. By way of a first test we have examined to what extent the inflation responsiveness to slack differs between the euro area and other parts of the OECD. For this purpose we estimated the following equation on quarterly data from the OECD Economic Outlook No. 77 database for the time period 1985Q1 to 2004Q4:

$$
\begin{aligned}
\pi_{t}^{i}=\sum_{j} & \alpha_{j}^{\pi}\left(\pi_{t-j}^{i}+\gamma_{t}^{i}\right)+\sum_{R \in\{€ ; E n g ; S ; J\}}\left(\alpha_{R}^{+} G A P^{+i R}+\alpha_{R}^{-} G A P_{t-1}^{{ }^{i} R}\right) \\
& +\sum_{k}\left(\alpha_{k}^{m} m_{t-k}^{i}+\alpha_{k}^{b} b_{t-k}^{i}+\alpha_{k}^{l} l_{t-k}^{i}+\alpha_{k}^{r} r_{t-k}^{i}\right)+c^{i}+d^{t}+\varepsilon_{t}^{i}
\end{aligned}
$$

11. Notations are as follows:

- $\quad \pi_{t}^{i}$ stands for annualised quarterly consumer price inflation in country $i$ over period $t$. This variable appears to be stationary as panel Augmented Dickey Fuller (ADF) tests reject the presence of individual unit roots at the $1 \%$ level.

- $\quad \gamma_{t}^{i}$ stands for the yield gap between 10-year government bond and money market rates.

- $\quad r_{t}^{i}$ denotes the logarithm of the real effective exchange rate, expressed in percentage points, taken from the OECD Main Economic Indicators.

- $G A P_{t}^{-i}{ }^{R}$ is by definition equal to the output gap of the country considered at time $t$ if the country belongs to region $R$ and the gap is negative and zero otherwise.

- $G A P_{t}^{+i^{R}}$ is the output gap of the country considered at time $t$ if the country belongs to region $R$ and the gap is positive, and zero otherwise.

12. Country data used in the panel has been divided between four geographic groupings:

- the euro area (except Greece, Ireland, Luxembourg and Portugal ${ }^{2}$ ) denoted by $€$,

- English-speaking countries (Australia, Canada, United Kingdom, New Zealand and the United States) denoted by Eng,

- Scandinavia (Denmark, Norway and Sweden) denoted by $S$, and

- $\operatorname{Japan}(J)$.

13. The regression includes controls for country and time varying supply shocks:

- $\quad m_{t}^{i}$ denotes the import price inflation, at annualised quarterly rate, scaled by the share of imports in total domestic expenditure,

2. Greece, Luxembourg and Portugal have been excluded because data on structural policy settings in these countries are incomplete in OECD databases. Ireland was taken out because its quarterly series for GDP are extremely volatile. 
- $\quad b_{t}^{i}$ denotes the change in the ratio of indirect taxes to private consumption in percentage points, annualised,

- $\quad l_{t}^{i}$ denotes trend labour productivity growth of the business sector, at annualised quarterly rate

14. Time fixed effects $d^{t}$ are introduced in the equation to capture the impact of common supply shocks such as oil price movements. Country fixed $c^{i}$ effects capture cross-country time-invariant differences in inflation responsiveness. The symbol $\varepsilon_{t}^{i}$ stands for the error term. The equation has been estimated using panel least squares and White's (1980) heteroskedasticity consistent covariances.

15. According to this specification inflation expectations are a combination of past inflation and future inflation (hybrid model). Past inflation expectations are presented through the lagged inflation, while the difference between long- and short-term rates (the yield gap) is used to approximate expected inflation changes. The rationale is that expected changes in inflation over the maturity period are the main component of deviations of the yield gap from its historical average (Mishkin, 1990). Therefore, inflation plus the deviation of the yield gap from its historical average can be used as a proxy for expected inflation - although the historical average of the yield gap can be omitted because it is captured by the country fixed effects included in the regressions. This variable is only imperfect approximation of long-term expectations of inflation as it also includes sovereign debt and exchange rate risks.

16. The main result from Equation (1) is that consumer price inflation responds much more sluggishly to output gap changes in the euro area than in English speaking countries (Table 1). A Wald test confirms that the difference between the coefficients before $\operatorname{GAP}_{t-1}^{€}(-0.13)$ and $\operatorname{GAP}_{t-1}^{E n g}(-0.58)$ is statistically significant at the $1 \%$ level.

17. Further interesting observations on Equation (1) can be made. First, the results confirm the assumption of the short-run Philips curve that predicts a positive relationship between the output and inflation: the coefficients on positive and negative gaps for the Euro area countries and English speaking countries are significant at $1 \%$ confidence level while the results on the group of Scandinavian countries is so at the $10 \%$ threshold. For Japan a significant coefficient is only found for the positive output gap. This result may be driven by deflation which is likely to have reduced the responsiveness of prices to slack (Mourougane and Ibaragi, 2004). Second, import prices weighted by the share of imports in total domestic expenditure have a strong impact on inflation, both un-lagged and lagged by one quarter. Third, indirect taxes also contribute to inflation, without a time lag. Fourth, increases in trend labour productivity have a tendency to reduce inflation, yet with a lag of two and three quarters. Fifth, the logarithm of the lagged real effective exchange rate was introduced to account for the tendency of prices to correct deviations from relative purchasing power parity. ${ }^{3}$ The coefficient on this variable is small but has the expected sign and is statistically significant at the $10 \%$ confidence level.

3. This is a departure from Honohan and Lane $(2003,2004)$ who assume absolute PPP (i.e. convergence to the same price level across countries) and thus directly introduce countries' purchasing power parities relative to the euro area in the equation. The justification is that relative PPP is better established in the empirical literature (see for instance Krugman and Obstfeld, 1994). Despite the conceptual difference between absolute and relative PPP, this choice has very limited importance in the methodological framework of this study. The inclusion of country fixed effects and the choice of a logarithmic form for the real effective exchange rate together imply that all estimated coefficients (other than those on the country dummies) are invariant to country-specific, time-invariant shifts in the level of PPPs. In order to ensure that the coefficients are approximately comparable to those in Honohan and Lane (2003, 2004), the logarithm of the real effective exchange rate is multiplied by 100 . 
Table 1: Estimated price equation with country group-specific output gap coefficients

\begin{tabular}{|c|c|c|}
\hline Explanatory variable & Coefficient & Standard error \\
\hline$\pi_{t-2}^{i}+\gamma_{t}^{i}$ & $0.17^{\star \star *}$ & 0.03 \\
\hline$G A P^{+^{i}{ }_{t-1} €}$ & $0.28^{\star \star *}$ & 0.10 \\
\hline$G A P^{-i}{ }_{t-1}^{i} €$ & $0.13^{\star \star *}$ & 0.05 \\
\hline$G A P^{+^{i}{ }_{t-1}}$ Eng & $0.91^{* * *}$ & 0.33 \\
\hline$G A P^{-^{i}{ }_{t-1}}{ }^{E n g}$ & $0.58^{\star * *}$ & 0.10 \\
\hline$G A P^{+^{i}{ }_{t-1} S}$ & $0.52^{*}$ & 0.29 \\
\hline$G A P^{-i}{ }_{t-1}^{S}$ & $0.23^{*}$ & 0.12 \\
\hline$G A P_{t-1}^{+^{i}}$ & $0.49^{* *}$ & 0.25 \\
\hline$G A P^{-i}{ }_{t-1}^{J}$ & 0.19 & 0.28 \\
\hline$m_{t}^{i}$ & $0.11^{* \star *}$ & 0.03 \\
\hline$m_{t-1}^{i}$ & $0.06^{\star \star}$ & 0.03 \\
\hline$b_{t}^{i}$ & $0.19^{\star *}$ & 0.10 \\
\hline$l_{t-2}^{i}$ & $-0.31^{* \star \star}$ & 0.06 \\
\hline$l_{t-3}^{i}$ & $-0.41^{\star \star \star}$ & 0.07 \\
\hline$r_{t-1}^{i}$ & $-0.02^{*}$ & 0.01 \\
\hline Adjusted $R^{2}$ & & 46 \\
\hline
\end{tabular}

Note:

${ }_{* * *}$ Statistically significantly different from zero at the $1 \%$ level.

** Statistically significantly different from zero at the $5 \%$ level.

* Statistically significantly different from zero at the $10 \%$ level

18. The lack of responsiveness of inflation to slack in the euro area can be related to structural rigidities. A number of issues stand out. First, inflation inertia is likely to be linked to the lack of integration and competition in the internal market for services (Vogt, 2005). Moreover, an observed weak cyclical sensitivity of consumer prices for non-energy industrial products (and their failure to decelerate when the euro appreciated despite their high import content) can be related to weak competition in retail services. Many distribution markets remain subject to a heavy regulatory burden at the national level - as highlighted in OECD (2005a). There may also be a link between inflation inertia and the labour market. Wage inflation in the euro area business sector barely decelerated when activity fell below potential, in stark contrast with Canada, Japan and the United States (OECD, 2005b). This observation is robust to the measure used, holding for hourly wages and the wage rate. We examine the relevance of these structural factors for the inflation responsiveness to slack in the next subsection. 


\subsection{Relating differences in inflation responsiveness to structural policy settings}

19. The main ambition of this paper is to relate differences in inflation dynamics to dissimilarities in structural policy settings. To this end, similar to the investigations by Nunziata and Bowdler (2005), quarterly inflation has been regressed on its own lags as well as on inflation expectations, on the output gap, on an interaction term aimed at capturing the effect of structural policies on the inflation response to the output gap as well as on the number of supply shocks (import prices, indirect taxes, productivity). In Equation (2), the output gap has again been separated in two variables which respectively cover its positive and negative values to account for asymmetries in the way institutional settings interact with the inflation process. While rigidities in product and factor markets may be expected to fuel inflationary pressures when the economy is growing above potential we found no evidence of this in our regression results, but they are found to weaken the extent to which prices decelerate at times of slack. So the former effect has been omitted in our final Equation (2) which has been estimated for a panel of 17 OECD countries including eight euro area countries: ${ }^{4}$

$$
\begin{aligned}
\pi_{t}^{i}= & \sum_{j} \beta_{j}^{\pi}\left(\pi_{t-j}^{i}+\gamma_{t}^{i}\right)+\beta^{G+} G A P^{+{ }_{t-1}^{i}}+\beta^{G-} G A P^{-i}{ }_{t-1}^{i}+\beta^{P} \nabla P O L_{t}^{i} \cdot G A P^{{ }^{i}}{ }_{t-1} \\
& +\sum_{k}\left(\beta_{k}^{m} m_{t-k}^{i}+\beta_{k}^{b} b_{t-k}^{i}+\beta_{k}^{l} l_{t-k}^{i}+\beta_{k}^{r} r_{t-k}^{i}\right)+c^{i}+d^{t}+\varepsilon_{t}^{i}
\end{aligned}
$$

20. The variables are the same as in Equation (1) and are denoted by the same symbols except that:

- $G A P^{+^{i}}{ }_{t-1}$ stands for the previous quarter's output gap if it is positive,

- $G A P^{-i}{ }_{t-1}^{i}$ stands for the previous quarter's output gap if it is negative,

- $\quad \nabla P O L_{t}^{i}$ denotes the normalised deviation of the structural policy indicator value from the full sample average (over $i$ and $t$ ) denoted $\overline{P O L}$; in other words $\nabla P O L_{t}^{i}=\frac{P O L_{t}^{i}-\overline{P O L}}{\operatorname{Max}_{i, t}\left|P O L_{t}^{i}-\overline{P O L}\right|}$. The variable $\nabla P O L_{t}^{i}$ can only take values in the interval between -1 and 1 and for an "average" observation its value is zero.

The data is taken from the OECD Economic Outlook No. 77 database, except for the real effective exchange rates which are taken from OECD's Main Economic Indicators database.

21. The following three structural policy indicators, which take higher values in less competitive settings, have been used. These structural policy variables have been used in previous OECD work. All structural variables are time varying: ${ }^{5}$

4. The countries in the sample are Australia, Austria, Belgium, Canada, Denmark, Finland, France, Germany, Italy, Japan, the Netherlands, New Zealand, Norway, Spain, Sweden, the United Kingdom and the United States.

5. Two more structural policy variables have been used in the regression analysis, replacement ratio of unemployment benefit and union density, but these did not prove to be statistically significant. 
- Employment protection legislation. This index of employment protection legislation for regular workers is taken from the OECD Employment Outlook 2004, Chapter 2. To the three components of this indicator belong procedural inconveniences, direct cost of dismissals and delays of dismissals. Original annual data has been extrapolated to quarterly frequency by repeated values. Original data covers the period of 1985-2002, it has been extended to 2004 by the end value.

- Concentration in wage setting. It measures the degree of coordination or centralisation in wage setting, constructed using data from the OECD Employment Outlook 2004, Chapter 3. The scale is 1- 3 where the lowest value corresponds to lowest level of centralization of wage setting (that takes place predominantly at company or fragmented industry level or at the combination of industry and company level) or lowest level of coordination of wage setting (little or no patternsetting). The middle value stands for industry-level predominant wage setting or industry-level bargaining with irregular pattern-setting and moderate co-ordination among major bargaining actors. The highest value stands for central-level agreements or following types of coordination: a) informal co-ordination of industry and firm-level bargaining by (multiple) peak associations, b) co-ordinated bargaining by peak confederations, including government-sponsored negotiations (tripartite agreements, social pacts), or government imposition, c) regular pattern-setting coupled with high union concentration and/or bargaining co-ordination by large firms, d) government wage arbitration, e) informal co-ordination of industry-level bargaining by an encompassing union confederation, f) co-ordinated bargaining by peak confederations or government imposition of a wage schedule/freeze, with a peace obligation. The data covers the period of 1985-2004. It has been extrapolated to quarterly frequency.

- Product market regulation. This is an indicator of the stringency of regulations in seven energy and service industries constructed by Nicoletti and Scarpetta (2003). This measure reflects trade barriers (tariff and non-tariff), barriers to entry, public ownership, price controls, government involvement in business operation, market concentration etc. The indicator takes its values on a 0-6 scale with a higher score corresponding to a more stringent regulations in the considered product markets. Original annual data has been extrapolated to quarterly frequency by repeating values. Original data covers the period of 1985-2003, but has been extended to 2004 by assuming no change from 2003 values.

22. Figure 2 and Table 2 present summary statistics for the structural policy indicators. The first observation to be made is that the indicators are strongly correlated across countries. Low (i.e. better) scores are consistently found among the "English-speaking" economies, where wage formation is not centralised, while employment protection legislation is lean and regulatory reform has progressed most. A second observation is that product market regulation has overall become leaner and converged towards a lower common level. In contrast, cross-country dispersion has remained broadly stable for the two labour market indicators.

23. In the first instance we estimated a version of the model without any of the structural indicators (benchmark model). The benchmark model (first column in Table 3) has been estimated by panel ordinary least squares (POLS). Robustness checks have been performed with the generalised method of moments (GMM) and two-stage least squares (2SLS), using lags of the regressors as instruments. These regressions yield similar results. The number of lags is optimal for both Akaike's and Schwarz's criteria. The significance levels reported below are based on White's (1980) heteroskedasticity consistent covariances. 
24. Given the rather strong cross-country correlation of the structural indicators it proved difficult to discriminate between them. Therefore we present three versions of the model, each time incorporating one of the three structural indicators. The version of the model which allows structural policy indicators to interact with the inflation response to cyclical slack, uncovers a statistically significant link between more rigid structural policy settings and a more muted deceleration of prices when the output gap is negative (next three columns of Table 3). The coefficient on the interaction variable at times of slack $\left(\nabla P O L^{*} G A P^{-}\right)$is negative and statistically different from zero at the $1 \%$ confidence level. The interaction with positive output gaps was never significant and therefore removed.

Figure 2: Average values for the three structural policy indicators (1985-2004)

\section{Employment protection legislation}

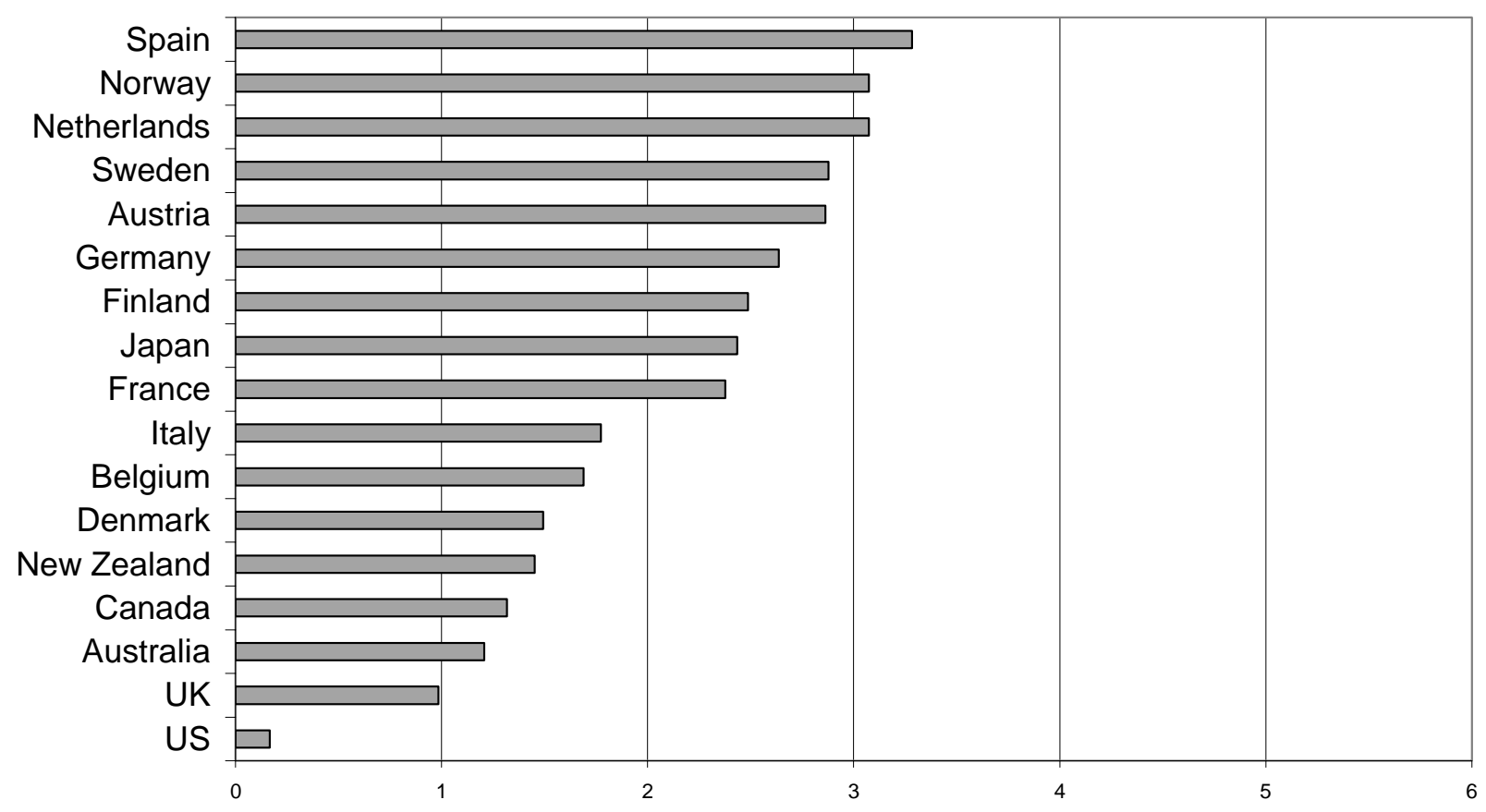




\section{Concentration of wage setting}

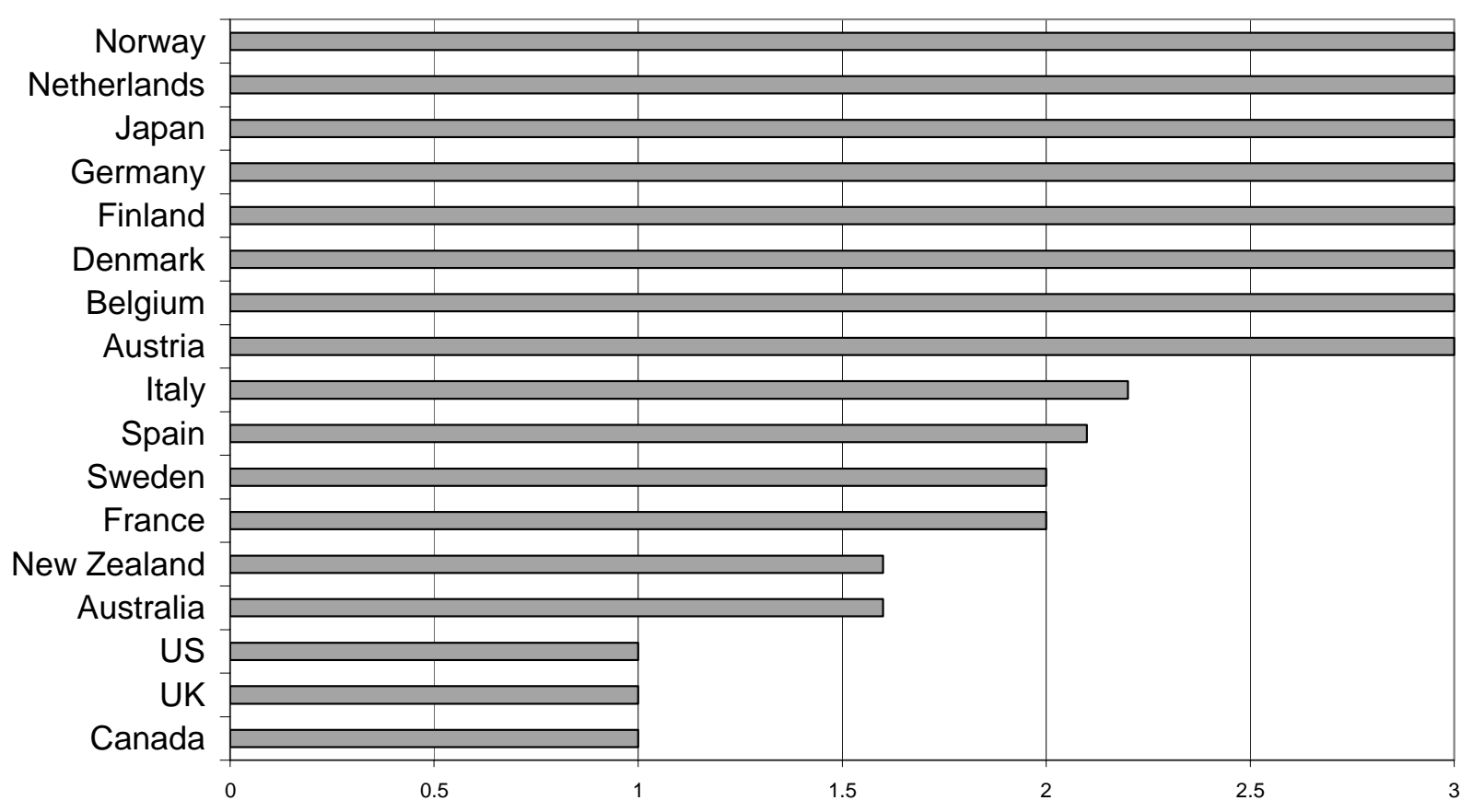

Regulatory reform in product markets

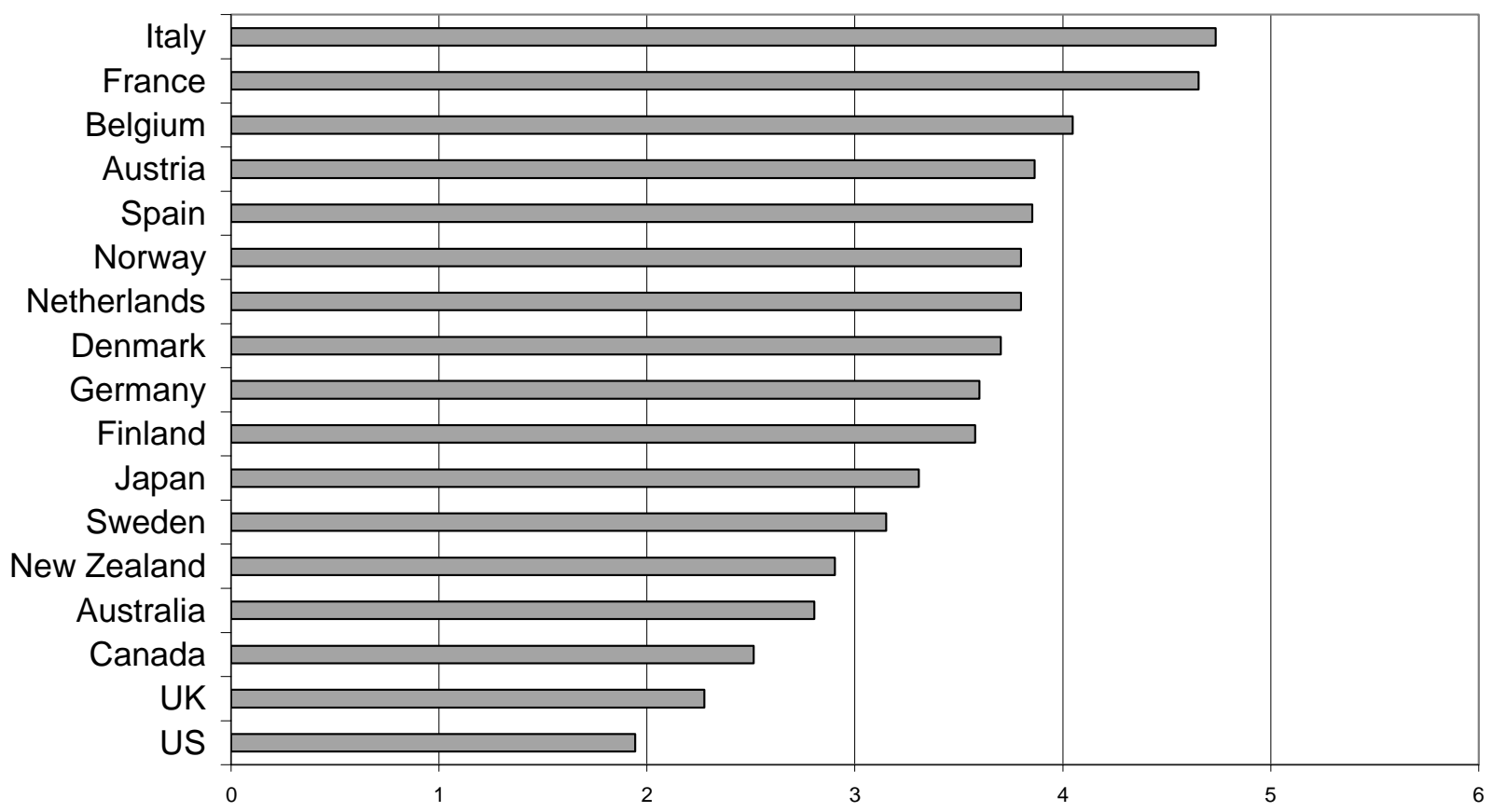


Table 2: Structural policy indicators (beginning and end-of-period values)

\begin{tabular}{|c|c|c|c|c|c|c|}
\hline & \multicolumn{2}{|c|}{$\begin{array}{l}\text { Employment protection } \\
\text { legislation }{ }^{1}\end{array}$} & \multicolumn{2}{|c|}{$\begin{array}{l}\text { Concentration in } \\
\text { wage setting }\end{array}$} & \multicolumn{2}{|c|}{$\begin{array}{l}\text { Product market } \\
\text { regulation }\end{array}$} \\
\hline & 1985 & 2004 & 1985 & 2004 & 1985 & 2004 \\
\hline Australia & 1 & 1.5 & 3.0 & 1.0 & 4.0 & 1.5 \\
\hline Austria & 2.9 & 2.4 & 3.0 & 3.0 & 4.9 & 2.4 \\
\hline Belgium & 1.7 & 1.7 & 3.0 & 3.0 & 5.5 & 2.1 \\
\hline Canada & 1.3 & 1.3 & 1.0 & 1.0 & 4.0 & 1.9 \\
\hline Germany & 2.6 & 2.7 & 3.0 & 3.0 & 5.1 & 1.7 \\
\hline Denmark & 1.5 & 1.5 & 3.0 & 3.0 & 5.5 & 1.6 \\
\hline Spain & 3.9 & 2.6 & 3.0 & 2.0 & 5.0 & 2.0 \\
\hline Finland & 2.8 & 2.2 & 3.0 & 3.0 & 5.1 & 2.4 \\
\hline France & 2.5 & 2.5 & 2.0 & 2.0 & 6.0 & 3.0 \\
\hline United Kingdom & 0.9 & 1.1 & 1.0 & 1.0 & 4.3 & 1.0 \\
\hline Italy & 1.8 & 1.8 & 1.0 & 3.0 & 5.8 & 2.6 \\
\hline Japan & 2.4 & 2.4 & 3.0 & 3.0 & 5.1 & 2.2 \\
\hline Netherlands & 3.1 & 3.1 & 3.0 & 3.0 & 5.7 & 1.6 \\
\hline Norway & 2.3 & 2.3 & 3.0 & 3.0 & 5.0 & 2.3 \\
\hline New Zealand & 1.4 & 1.7 & 3.0 & 1.0 & 4.5 & 2.1 \\
\hline Sweden & 2.9 & 2.9 & 2.0 & 2.0 & 4.5 & 1.9 \\
\hline $\begin{array}{l}\text { United States } \\
\text { Arithmetic }\end{array}$ & 0.2 & 0.2 & 1.0 & 1.0 & 2.5 & 1.4 \\
\hline average & 2.1 & 2.0 & 2.4 & 2.2 & 4.9 & 2.0 \\
\hline deviation & 0.9 & 0.7 & 0.8 & 0.9 & 0.8 & 0.5 \\
\hline $\begin{array}{ll}\text { Notes: } \\
\begin{array}{l}\text { Notes } \\
2\end{array} \\
3\end{array}$ & & & & & & \\
\hline
\end{tabular}

25. The upshot is that stronger labour and product market rigidities are associated with a smaller decline in inflation when the output gap moves into negative territory. As a result, the estimated response of inflation to a widening negative output gap is much weaker in euro area countries, which score higher on structural rigidity indicators, than the English-speaking countries present in the sample (Table 4).

26. The regressions have again been replicated with different estimation methods namely two-stage least squares (2SLS) and the generalised method of moments (GMM). Lags of the regressors have been used as instruments for 2SLS and GMM. The results are very similar with slightly higher confidence levels, as expected since covariance estimators are absolutely unbiased at all sample sizes in POLS but are only asymptotically unbiased in 2SLS and GMM. For all equations, the estimation results hold if time fixed effect ("time dummies") are omitted. The estimated coefficients are very similar and are obtained at comparable (or in some cases slightly lower) confidence levels. This suggests that the controls are capturing a large part of the impact of symmetric supply shocks. 
Table 3. Estimated price equations: baseline model

1985Q1 - 2004Q4, standard errors in brackets

\begin{tabular}{|c|c|c|c|c|}
\hline \multirow[t]{2}{*}{ Explanatory variable } & \multirow{2}{*}{$\begin{array}{l}\text { Without structural policy } \\
\text { indicator }\end{array}$} & \multicolumn{3}{|c|}{ Structural policy indicator used } \\
\hline & & $\begin{array}{l}\text { Concentration in wage } \\
\text { setting }\end{array}$ & $\begin{array}{l}\text { Employment protection } \\
\text { legislation }\end{array}$ & $\begin{array}{l}\text { Product market } \\
\text { regulation }\end{array}$ \\
\hline$\pi_{t-2}^{i}+\gamma_{t}^{i}$ & $0.16^{\star \star \star}(0.03)$ & $0.17^{\star \star \star}(0.03)$ & $0.16^{* \star *}(0.03)$ & $0.16^{\star \star \star}(0.03)$ \\
\hline$G A P^{+_{t-1}^{i}}$ & $0.51^{\star \star \star}(0.11)$ & $0.52^{\star \star \star}(0.11)$ & $0.50^{\star \star \star}(0.11)$ & $0.51^{\star * \star}(0.11)$ \\
\hline$G A P^{-i}{ }_{t-1}$ & $0.22^{\star \star \star}(0.04)$ & $0.27^{\star \star \star}(0.05)$ & $0.29^{\star \star \star}(0.04)$ & $0.26^{\star \star \star}(0.05)$ \\
\hline$\nabla P O L_{t}^{i} \cdot G A P^{-^{i}}{ }_{t-1}$ & & $-0.27^{\star \star \star}(0.05)$ & $-0.48^{\star \star \star}(0.11)$ & $-0.29^{\star \star *}(0.10)$ \\
\hline$m_{t}^{i}$ & $0.10^{\star \star \star}(0.03)$ & $0.10^{\star \star \star}(0.03)$ & $0.10^{* \star *}(0.03)$ & $0.10^{\star * \star}(0.03)$ \\
\hline$m_{t-1}^{i}$ & $0.05^{*}(0.03)$ & $0.06^{* *}(0.03)$ & $0.05^{\star \star}(0.03)$ & $0.05^{\star *}(0.03)$ \\
\hline$b_{t}^{i}$ & $0.20^{*}(0.10)$ & $0.19 *(0.10)$ & $0.20^{*} \quad(0.10)$ & $0.20^{*} \quad(0.10)$ \\
\hline$l_{t-2}^{i}$ & $-0.31^{* \star *}(0.06)$ & $-0.29^{\star \star *}(0.06)$ & $-0.32^{* \star \star}(0.07)$ & $-0.33^{\star \star \star}(0.07)$ \\
\hline$l_{t-3}^{i}$ & $-0.42^{\star \star \star}(0.07)$ & $-0.41^{* \star *}(0.07)$ & $-0.44^{* \star *}(0.08)$ & $-0.44^{* \star *}(0.08)$ \\
\hline $\begin{array}{l}r_{t-1}^{i} \\
\text { Adjusted } R^{2}\end{array}$ & $\begin{array}{cc}-0.02^{*}(0.01) \\
& 0.44\end{array}$ & $\begin{array}{c}-0.02^{*}(0.01) \\
0.45\end{array}$ & $\begin{array}{c}-0.02^{*}(0.01) \\
0.45\end{array}$ & $\begin{array}{ll}-0.02^{*} & (0.01) \\
0.45 & \end{array}$ \\
\hline Number of observations & 1360 & 1360 & 1360 & 1360 \\
\hline
\end{tabular}

Note:

$\star * * \quad$ Significance at the $1 \%$ level.

** Significance at the $5 \%$ level.

* Significance at $10 \%$ level.

27. The estimation results also confirm that present inflation outcomes are related to past inflation as coefficients on lagged inflation are positive and statistically significant at the $1 \%$ level in all estimated equations. However, Equation (2) imposes common autoregressive terms across countries. It can be argued that country fixed effects may not be sufficient to capture idiosyncrasies (such as the degree of independence of monetary authorities) and that country-specific autoregressive coefficients are called for. Therefore Equation (2) has been re-estimated with country-specific autoregressive coefficients. The results are similar to those shown in table 3. For each structural variable, the coefficient on the interaction term $\left(\nabla P O L^{*} G A P^{-}\right)$exhibits the same sign as in table 3 and is statistically significant coefficients at the $5 \%$ confidence level. ${ }^{6}$

6. Detailed results are available from the authors upon request. 
Table 4. The impact of slack on inflation

Simulated inflation fall induced by a $-1 \%$ output gap ${ }^{1}$

\begin{tabular}{lccc}
\hline & \multicolumn{2}{c}{ Structural indicator used in the regression } \\
\cline { 2 - 4 } & $\begin{array}{c}\text { Concentration in } \\
\text { wage bargaining }\end{array}$ & $\begin{array}{c}\text { Employment } \\
\text { protection } \\
\text { legislation }\end{array}$ & $\begin{array}{c}\text { Product market } \\
\text { regulation }\end{array}$ \\
\hline Euro area countries & & & \\
Austria & 0.1 & 0.1 & 0.2 \\
Belgium & 0.1 & 0.4 & 0.2 \\
Finland & 0.1 & 0.2 & 0.2 \\
France & 0.3 & 0.2 & 0.1 \\
Germany & 0.1 & 0.1 & 0.2 \\
Italy & 0.3 & 0.4 & 0.1 \\
Netherlands & 0.1 & 0.0 & 0.2 \\
Spain & 0.3 & 0.0 & 0.2 \\
Average & 0.2 & 0.2 & 0.2 \\
Other countries & & & \\
Australia & & & \\
Canada & 0.4 & 0.5 & 0.3 \\
Denmark & 0.5 & 0.5 & 0.4 \\
Japan & 0.1 & 0.4 & 0.2 \\
New Zealand & 0.1 & 0.2 & 0.3 \\
Norway & 0.4 & 0.4 & 0.3 \\
Sweden & 0.1 & 0.0 & 0.2 \\
United Kingdom & 0.3 & 0.1 & 0.3 \\
United States & 0.5 & 0.6 & 0.4 \\
Average & 0.5 & 0.8 & 0.4 \\
\hline
\end{tabular}

1. Inflation relates to the annualised quarterly change in the consumer price index. The results shown here are based on the coefficients drawn from Table 3.

28. As noted, it proves hard to discriminate between the different structural indicators when all three of them are included in the regression equation. This is somewhat unsatisfactory, because it would be useful to know what matters most for inflation persistence: product market or labour market rigidities. Fortunately, introducing two interaction terms $(\mathrm{GAP} * \nabla \mathrm{POL})$ does provide satisfactory results. Out of three possible combinations of structural variables only one did not yield statistically significant results: the interaction variable of regulatory reform and that of concentration of wage setting, while other combinations provide results where both interactions show expected sign and are statistically significant (Table 5). The most powerful combination (both coefficients significant at the 5\% level) is that of employment protection legislation and concentration in wage setting. This suggests that labour market rigidities are a predominant source of inflation persistence in the face of slack in the euro area, although the apparent impact of product market rigidities should not be dismissed. 


\section{ECO/WKP(2005)22}

Table 5. Estimated price equations with pairs of structural policy indicators 1985Q1 - 2004Q4, standard errors in brackets

\begin{tabular}{|c|c|c|c|c|}
\hline \multirow[t]{2}{*}{ Explanatory variable } & \multirow{2}{*}{$\begin{array}{l}\text { Without structural } \\
\text { policy indicator }\end{array}$} & \multicolumn{3}{|c|}{ Structural policy indicators used } \\
\hline & & $\begin{array}{l}\text { Employment protection } \\
\text { and concentration in } \\
\text { wage setting }\end{array}$ & $\begin{array}{c}\text { Product market } \\
\text { regulation and } \\
\text { employment protection } \\
\text { legislation }\end{array}$ & $\begin{array}{c}\text { Product market } \\
\text { regulation and } \\
\text { concentration in wage } \\
\text { setting }\end{array}$ \\
\hline$\pi_{t-2}^{i}+\gamma_{t}^{i}$ & $0.16^{\star \star \star}(0.03)$ & $0.17^{\star \star \star}(0.03)$ & $0.17^{\star \star \star}(0.03)$ & $0.17^{\star \star \star}(0.03)$ \\
\hline$G A P_{t-1}^{+^{i}}$ & $0.51^{\star \star \star}(0.11)$ & $0.51^{\star \star \star}(0.11)$ & $0.50^{\star \star \star}(0.11)$ & $0.52^{\star \star \star}(0.11)$ \\
\hline$G A P^{-i}{ }_{t-1}^{i}$ & $0.22^{\star \star \star}(0.04)$ & $0.29^{\star \star \star}(0.04)$ & $0.30^{\star \star *}(0.04)$ & $0.28^{\star \star \star}(0.05)$ \\
\hline$\nabla P O L_{t}^{i} \cdot G A P^{-i}{ }_{t-1}^{i}$ & .. & $-0.31^{* \star}(0.13)$ & $-0.17^{\star} \quad(0.10)$ & $-0.12 \quad(0.11)$ \\
\hline$\nabla P O L_{t}^{2^{i}} \cdot G A P^{-^{i}}{ }_{t-1}$ & .. & $-0.17^{* \star}(0.07)$ & $-0.44^{\star \star \star}(0.11)$ & $-0.24^{\star \star \star}(0.06)$ \\
\hline$m_{t}^{i}$ & $0.10^{* \star \star}(0.03)$ & $0.10^{* \star *}(0.03)$ & $0.10^{\star \star *}(0.03)$ & $0.10^{\star \star \star}(0.03)$ \\
\hline$m_{t-1}^{i}$ & $0.05^{\star} \quad(0.03)$ & $0.05^{\star *}(0.03)$ & $0.05^{* *}(0.03)$ & $0.06^{* *}(0.03)$ \\
\hline$b_{t}^{i}$ & $0.20^{*} \quad(0.10)$ & $0.19^{*} \quad(0.10)$ & $0.20^{*} \quad(0.10)$ & $0.19^{*} \quad(0.10)$ \\
\hline$l_{t-2}^{i}$ & $-0.31^{* \star *}(0.06)$ & $-0.31^{* * *}(0.06)$ & $-0.33^{* \star \star}(0.08)$ & $-0.30^{* \star *}(0.06)$ \\
\hline$l_{t-3}^{i}$ & $-0.42^{\star \star \star}(0.07)$ & $-0.42^{\star \star \star}(0.07)$ & $-0.45^{\star \star \star}(0.08)$ & $-0.42^{\star \star \star}(0.07)$ \\
\hline$r_{t-1}^{i}$ & $-0.02^{\star} \quad(0.01)$ & $-0.02^{\star} \quad(0.01)$ & $-0.02^{\star \star}(0.01)$ & $-0.02^{*} \quad(0.01)$ \\
\hline Adjusted $R^{2}$ & 0.44 & 0.45 & 0.45 & 0.45 \\
\hline $\begin{array}{l}\text { Number of } \\
\text { observations }\end{array}$ & 1360 & 1360 & 1360 & 1360 \\
\hline
\end{tabular}

Note:

${ }_{* * *}$ Significance at the $1 \%$ level.

** Significance at the $5 \%$ level.

* Significance at $10 \%$ level. 
29. A further observation should be made. The above result suggests that, while strong wage coordination may induce a net welfare gain under "normal" circumstances, some of this gain may be lost at times of cyclical slack in the face of near-zero inflation. The widely accepted "hump-shaped" relationship between the degree of wage co-ordination and structural unemployment predicts that strong wage coordination helps smoothing the cycle through appropriate real wage adjustment, notably in small open economies that are vulnerable to external shocks (Elmeskov et al., 1998). ${ }^{7}$ However, experiments with the inclusion of such a hump-shaped relationship in the regression equations failed. It is indeed not obvious that, in a low inflation environment, a combination of strict employment legislation and strong wage coordination would contribute to downward flexibility of nominal wages and prices in the face of slack. For example, Holden (2004) notes that: "In most European countries, the prevailing terms of employment, including the nominal wage, can only be changed by mutual consent. If inflation is so low that nominal wages have to be cut, the workers have strategic advantage in the wage negotiations, which induces higher unemployment in equilibrium. (...) Specifically, downward nominal wage rigidity and excess unemployment at zero inflation are related to three factors: the coverage of collective agreements, the legal framework at contract renewal, and the strictness of the employment protection legislation for non-union workers."

\section{Further robustness checks}

30. In order to ascertain that our main findings are not distorted by problems of misspecification, we carried out a number of robustness tests. We have looked at three possible sources of distortions:

- the possibility that part or all of the identified downward inflation inertia in the euro are may be due to the adoption of the single currency itself (as opposed to structural rigidities) and the associated move towards a credible low-inflation environment;

- The possibility that the main findings depend on the choice of the output gap measure, given that this is a construct involving prior judgment and based on empirical (country-specific) Phillips curves whose specification may not be identical to the Phillips curves we estimate;

- The possibility that the main findings break down once a long-run vertical Phillips curve is assumed (i.e. if the coefficients on lagged inflation are assumed to sum to unity).

\subsection{The adoption of the euro}

31. What is common for the set of the euro area countries since the beginning of the 1990s is a move to a monetary management marked by low inflation environment in the context of the euro adoption. By anchoring a low inflation regime, the adoption of the euro may have rendered downward nominal rigidities more apparent. A possible theoretical underpinning of this assumption is the existence of the nominal wage floor. As the theory goes, nominal wages never decrease as economic agents do not accept nominal wage cuts. In reality, such a floor is probably at $1 \%$ of nominal wage growth for many countries. With a change to a lower inflation environment, due to nominal wage floors, the lower part of the curve becomes horizontal as inflation becomes completely inelastic to output changes once the nominal floor is achieved.

7. Decentralised wage bargaining at the firm level is usually regarded as employment-friendly, preventing excessive wage claims since this would lead to a loss of market shares to competitors with detrimental effects on employment. At the other extreme, very centralised or coordinated bargaining systems induce bargaining parties to internalise the detrimental effects on employment that excessive wage pressure can have at the macroeconomic level. Intermediate-level wage bargaining, on the other hand, would tend to yield the worst labour market outcomes, as it neither internalises the impact of wage demands on individual firms and local job prospects, nor of macroeconomic externalities associated with centralised wage bargaining. 


\section{ECO/WKP(2005)22}

32. This begs the question as to whether there the move towards a credible low-inflation environment has played an independent role over and above persistent structural rigidities as a source of inflation persistence in the face of slack in the euro area. This issue has been investigated by interacting the regressors with dummy variables which are equal to one for euro area countries after a given reference date and zero otherwise. Three points in time have been considered in turn: 1992Q4 for the ratification of the Maastricht treaty by a majority of member states ("Maastricht" dummy variable) as this committed EU countries to portray inflation convergence towards the best performers in order to qualify for the single currency, 1999Q1 for the adoption of the euro ("euro" dummy variable), 2002Q1 for the cash changeover ("cash" dummy variable). Explanatory variables have been interacted with the dummy variables one by one. For instance, the following equation has been estimated to detect a break on the negative output gap coefficient:

$$
\begin{aligned}
\pi_{t}^{i}= & \sum_{j} \beta_{j}^{\pi}\left(\pi_{t-j}^{i}+\gamma_{t}^{i}\right)+\beta^{G+} G A P^{+{ }_{t-1}^{i}}+\beta^{G-} G A P^{-^{i}}{ }_{t-1}+\beta^{P} \nabla P O L_{t}^{i} \cdot G A P^{-^{i}}{ }_{t-1} \\
& +\sum_{k}\left(\beta_{k}^{m} m_{t-k}^{i}+\beta_{k}^{b} b_{t-k}^{i}+\beta_{k}^{l} l_{t-k}^{i}+\beta_{k}^{r} r_{t-k}^{i}\right)+c^{i}+d^{t}+ \\
& +\widetilde{\beta}^{G+} G A P^{+{ }^{i}}{ }_{t-1} \cdot D U M_{t}{ }_{t}^{i}+\widetilde{\beta}^{G-} G A P^{-{ }^{i}}{ }_{t-1} \cdot D U M_{t}^{i}+\varepsilon_{t}^{i}
\end{aligned}
$$

33. The results of this regression that are presented in Tables 6,7 and 8, point to a structural break on the negative output gap coefficient. The coefficient on the negative output gap interacted with the structural break dummy (denoted by $\widetilde{\beta}^{G-}$ in Equation 3 above) is negative and statistically significant at the $1 \%$ confidence level for the Euro and Cash euro dummies with all three structural indicators. Yet, the most important conclusion for our purpose is that the introduction of structural break dummies does not alter the previous results since the coefficient on the interaction term $\left(G A P^{*} \nabla P O L\right)$ remains negative in a statistically significant way. Strikingly, the coefficient on the $G A P^{*} D U M$ term is approximately twice as large as that on $G A P^{*} \nabla P O L$. Although the interpretation of the size of the coefficients is not unambiguous, this result suggests that the establishment of a credible low inflation targeting framework might have resulted in a looser link between inflation developments and output conditions. 
ECO/WKP(2005)22

Table 6. Estimated price equations with concentration in wage setting and structural breaks 1985Q1 - 2004Q4, standard errors in brackets

\begin{tabular}{|c|c|c|c|c|}
\hline \multirow[t]{2}{*}{ Explanatory variable } & \multirow{2}{*}{$\begin{array}{c}\text { No dummy variable } \\
\text { used }\end{array}$} & \multicolumn{3}{|c|}{ Dummy variable used } \\
\hline & & Maastricht & Euro & Cash euro \\
\hline$\pi_{t-2}^{i}+\gamma_{t}^{i}$ & $0.17^{\star * *}(0.03)$ & $0.17^{* * *}(0.03)$ & $0.17^{\star * *}(0.03)$ & $0.17^{\star * \star}(0.03)$ \\
\hline$G A P^{+^{i}}{ }_{t-1}$ & $0.52^{\star * *}(0.11)$ & $0.52^{* * *}(0.13)$ & $0.54^{\star * *}(0.12)$ & $0.53^{* * *}(0.11)$ \\
\hline$G A P^{-i}{ }_{t-1}$ & $0.27^{\star \star \star}(0.05)$ & $0.29^{\star \star \star}(0.06)$ & $0.28^{* * *}(0.05)$ & $0.28^{\star * \star}(0.05)$ \\
\hline$\nabla P O L_{t}^{i} \cdot G A P^{-i}{ }_{t-1}$ & $-0.27^{\star \star \star}(0.05)$ & $-0.24^{\star \star *}(0.06)$ & $-0.27^{\star \star \star}(0.05)$ & $-0.27^{\star * *}(0.05)$ \\
\hline$m_{t}^{i}$ & $0.10^{\star * *}(0.03)$ & $0.10^{* \star *}(0.03)$ & $0.10^{\star \star *}(0.03)$ & $0.10^{* * *}(0.03)$ \\
\hline$m_{t-1}^{i}$ & $0.06^{* *}(0.03)$ & $0.06^{\star *}(0.03)$ & $0.06^{\star *}(0.03)$ & $0.06^{\star *}(0.03)$ \\
\hline$b_{t}^{i}$ & $0.19^{*} \quad(0.10)$ & $0.19^{*}(0.10)$ & $0.18^{*}(0.10)$ & $0.18^{*} \quad(0.10)$ \\
\hline$l_{t-2}^{i}$ & $-0.29^{\star * *}(0.06)$ & $-0.29^{* \star \star}(0.06)$ & $-0.28^{* * *}(0.05)$ & $-0.28^{\star * *}(0.05)$ \\
\hline$l_{t-3}^{i}$ & $-0.41^{\star * *}(0.07)$ & $-0.41^{\star \star *}(0.07)$ & $-0.39^{* * *}(0.06)$ & $-0.39^{\star \star *}(0.06)$ \\
\hline$r_{t-1}^{i}$ & $-0.02^{*} \quad(0.01)$ & $-0.02^{*}(0.01)$ & $-0.02^{*} \quad(0.01)$ & $-0.02^{*}(0.01)$ \\
\hline$G A P^{+^{i}}{ }_{t-1} \cdot D U M_{t}^{i}$ & & $-0.04 \quad(0.17)$ & $-0.07 \quad(0.16)$ & $-0.28 \quad(0.61)$ \\
\hline$G A P_{t-1}^{-i} \cdot D U M_{t}^{i}$ & & $-0.06 \quad(0.08)$ & $-0.59^{\star * *}(0.15)$ & $-0.65^{\star \star *}(0.16)$ \\
\hline Adjusted $R^{2}$ & 0.45 & 0.44 & 0.45 & 0.45 \\
\hline Number of observations & 1360 & 1360 & 1360 & 1360 \\
\hline $\begin{array}{ll}\text { Note: } & \\
{ }_{* * *} & \text { Significance at the } \\
* * & \text { Significance at the } \\
* & \text { Significance at } 10^{\circ}\end{array}$ & $\begin{array}{l}\text { level. } \\
\text { level. } \\
\text { vel. }\end{array}$ & & & \\
\hline
\end{tabular}




\section{ECO/WKP(2005)22}

Table 7. Estimated price equations with employment protection legislation and structural breaks 1985Q1 - 2004Q4, standard errors in brackets

\begin{tabular}{|c|c|c|c|c|}
\hline \multirow[t]{2}{*}{ Explanatory variable } & \multirow{2}{*}{$\begin{array}{c}\text { No dummy variable } \\
\text { used }\end{array}$} & \multicolumn{3}{|c|}{ Dummy variable used } \\
\hline & & Maastricht & Euro & Cash euro \\
\hline$\pi_{t-2}^{i}+\gamma_{t}^{i}$ & $0.16^{* * *}(0.03)$ & $0.16^{* * *}(0.03)$ & $0.16^{* * *}(0.03)$ & $0.16^{* \star *}(0.03)$ \\
\hline$G A P^{+{ }_{t-1}^{i}}$ & $0.50^{\star \star \star}(0.11)$ & $0.48^{* * *}(0.13)$ & $0.51^{* * *}(0.12)$ & $0.50^{* \star *}(0.11)$ \\
\hline$G A P^{-i}{ }_{t-1}$ & $0.29^{\star \star \star}(0.04)$ & $0.34^{* * *}(0.06)$ & $0.30^{* * *}(0.05)$ & $0.30^{\star \star \star}(0.04)$ \\
\hline$\nabla P O L_{t}^{i} \cdot G A P^{-i}{ }_{t-1}$ & $-0.48^{\star * *}(0.11)$ & $-0.44^{* * *}(0.12)$ & $-0.48^{* * *}(0.11)$ & $-0.47^{\star \star \star}(0.11)$ \\
\hline$m_{t}^{i}$ & $0.10^{\star * *}(0.03)$ & $0.10^{\star \star \star}(0.03)$ & $0.10^{* * *}(0.03)$ & $0.10^{* \star *}(0.03)$ \\
\hline$m_{t-1}^{i}$ & $0.05^{\star *}(0.03)$ & $0.05^{* *}(0.03)$ & $0.05^{* *}(0.03)$ & $0.05^{\star \star}(0.03)$ \\
\hline$b_{t}^{i}$ & $0.20^{*} \quad(0.10)$ & $0.20^{*} \quad(0.10)$ & $0.19^{*} \quad(0.10)$ & $0.19^{*} \quad(0.10)$ \\
\hline$l_{t-2}^{i}$ & $-0.32^{\star \star *}(0.07)$ & $-0.31^{* * *}(0.07)$ & $-0.30^{* * *}(0.06)$ & $-0.31^{\star \star \star}(0.06)$ \\
\hline$l_{t-3}^{i}$ & $-0.44^{\star * \star}(0.08)$ & $-0.42^{* \star *}(0.08)$ & $-0.42^{\star \star \star}(0.07)$ & $-0.42^{* * *}(0.07)$ \\
\hline$r_{t-1}^{i}$ & $-0.02^{*} \quad(0.01)$ & $-0.02^{*} \quad(0.01)$ & $-0.02^{*} \quad(0.01)$ & $-0.02^{*} \quad(0.01)$ \\
\hline$G A P^{+^{i}}{ }_{t-1} \cdot D U M_{t}^{i}$ & & $0.01 \quad(0.17)$ & $0.00 \quad(0.16)$ & $-0.36 \quad(0.62)$ \\
\hline$G A P^{-^{i}}{ }_{t-1} \cdot D U M_{t}^{i}$ & & $-0.13^{*}(0.08)$ & $-0.57^{\star \star \star}(0.16)$ & $-0.58^{* * *}(0.17)$ \\
\hline Adjusted $R^{2}$ & 0.45 & 0.45 & 0.45 & 0.45 \\
\hline Number of observations & 1360 & 1360 & 1360 & 1360 \\
\hline $\begin{array}{ll}\text { Note: } & \\
* \star * & \text { Significance at the } \\
\star * & \text { Significance at the } \\
* & \text { Significance at } 10^{\circ}\end{array}$ & & & & \\
\hline
\end{tabular}


ECO/WKP(2005)22

Table 8. Estimated price equations with product market regulation and structural breaks

1985Q1 - 2004Q4, standard errors in brackets

\begin{tabular}{|c|c|c|c|c|}
\hline \multirow[t]{2}{*}{ Explanatory variable } & \multirow{2}{*}{$\begin{array}{c}\text { No dummy variable } \\
\text { used }\end{array}$} & \multicolumn{3}{|c|}{ Dummy variable used } \\
\hline & & Maastricht & Euro & Cash euro \\
\hline$\pi_{t-2}^{i}+\gamma_{t}^{i}$ & $0.16^{\star \star *}(0.03)$ & $0.16^{\star \star \star}(0.03)$ & $0.16^{\star \star \star}(0.03)$ & $0.16^{\star \star \star}(0.03)$ \\
\hline$G A P^{+^{i}}{ }_{t-1}$ & $0.51^{\star \star \star}(0.11)$ & $0.50^{\star \star \star}(0.13)$ & $0.53^{\star \star \star}(0.12)$ & $0.52^{* * *}(0.11)$ \\
\hline$G A P^{-i}{ }_{t-1}^{i}$ & $0.26^{\star \star \star}(0.05)$ & $0.34^{\star \star \star}(0.07)$ & $0.28^{\star \star \star}(0.05)$ & $0.29^{\star \star \star}(0.05)$ \\
\hline$\nabla P O L_{t}^{i} \cdot G A P^{-i}{ }_{t-1}^{i}$ & $-0.29^{* \star \star}(0.10)$ & $-0.27^{* \star \star}(0.10)$ & $-0.39^{* \star \star}(0.10)$ & $-0.38^{\star \star \star}(0.10)$ \\
\hline$m_{t}^{i}$ & $0.10^{\star \star \star}(0.03)$ & $0.10^{\star \star \star}(0.03)$ & $0.10^{\star \star \star}(0.03)$ & $0.10^{* * *}(0.03)$ \\
\hline$m_{t-1}^{i}$ & $0.05^{* *}(0.03)$ & $0.05^{\star \star}(0.03)$ & $0.06^{\star \star}(0.03)$ & $0.06^{\star *}(0.03)$ \\
\hline$b_{t}^{i}$ & $0.20^{*} \quad(0.10)$ & $0.20^{*} \quad(0.10)$ & $0.20^{*} \quad(0.10)$ & $0.20^{*} \quad(0.10)$ \\
\hline$l_{t-2}^{i}$ & $-0.33^{\star \star \star}(0.07)$ & $-0.31^{\star \star \star}(0.07)$ & $-0.31^{\star \star \star}(0.06)$ & $-0.32^{\star * \star}(0.06)$ \\
\hline$l_{t-3}^{i}$ & $-0.44^{* \star \star}(0.08)$ & $-0.43^{\star \star \star}(0.08)$ & $-0.43^{\star \star \star}(0.07)$ & $-0.43^{* \star \star}(0.07)$ \\
\hline$r_{t-1}^{i}$ & $-0.02^{*} \quad(0.01)$ & $-0.02^{\star} \quad(0.01)$ & $-0.02^{\star} \quad(0.01)$ & $-0.02^{*} \quad(0.01)$ \\
\hline$G A P_{t-1}^{+i} \cdot D U M_{t}^{i}$ & & $-0.06 \quad(0.17)$ & $-0.05 \quad(0.17)$ & $-0.41 \quad(0.58)$ \\
\hline $\begin{array}{l}G A P^{-}{ }_{t-1}^{t} \cdot D U M_{t}^{i} \\
\text { Adjusted } R^{2}\end{array}$ & 0.44 & $\begin{array}{c}-0.20^{\star \star \star}(0.07) \\
0.44\end{array}$ & $\begin{array}{c}-0.80^{* \star \star}(0.17) \\
0.44\end{array}$ & $\begin{array}{c}-0.84^{\star \star \star}(0.18) \\
0.44\end{array}$ \\
\hline $\begin{array}{l}\text { Number of } \\
\text { observations }\end{array}$ & 1360 & 1360 & 1360 & 1360 \\
\hline
\end{tabular}

\subsection{Mind the gap}

34. Output gaps are not observed and sizeable discrepancies can exist between different measures (see Cotis et al., 2005 for a recent survey of this issue). It is therefore important to check whether the results are sensitive to the output gap measure that has been used in the regression. The results reported in this paper have been obtained with the standard OECD output gap, as found in the OECD Economic Outlook No. 77 database. The OECD gap assumes symmetry in the reaction of inflation to output gaps over the estimation period. To check that the results are not driven by this hypothesis, we replicate our regressions with an alternative, "mechanical" gap that does not rest on an implicit assumption about inflation behaviour.

35. An alternative measure of the output gap has been derived as follows. A simple log-linear trend has been estimated with ordinary least squares for each country $i: \ln \left(Y_{t}^{i}\right)=\alpha^{i}+\beta^{i} * t+\varepsilon_{t}$ where $Y_{t}^{i}$ denotes output volume in country $i$ during period $t ; \alpha^{i}$ and $\beta^{i}$ are the coefficients of interest; and $\varepsilon_{t}$ is the 
error term in the regression. The output gap is then computed as the percentage difference between $Y_{t}^{i}$ and $e^{\alpha^{i}+\beta^{i} t}$. The regressions have then been rerun with this measure of the output gap. ${ }^{8}$

36. The baseline results appear to be robust to the choice of the output gap measure. The alternative output gap measure yields very similar results to those obtained with the standard OECD output gap in all but one case (Table 9). Thus, the findings are robust with the only exception of the regression using the indicator of product market regulations. However, this structural policy index raises specific, technical estimation issues because it exhibits a common, downward trend across countries. When this common trend is removed, in line with the focus on cross-country differences, the results obtained with the regulatory reform index hold for both measures of the output gap. This result may be taken to suggest that cross-country differences in regulatory regimes predominate over the overall stance of regulatory policy in explaining downward inflation rigidity. This is broadly in line with findings reported in CPB (2004).

Table 9. Estimated price equations with an alternative output gap measure

1985Q1 - 2004Q4, standard errors in brackets

\begin{tabular}{|c|c|c|c|c|c|}
\hline \multirow[t]{2}{*}{ Explanatory variable } & \multirow{2}{*}{$\begin{array}{l}\text { Without } \\
\text { structural policy } \\
\text { indicator }\end{array}$} & \multicolumn{4}{|c|}{ Structural policy indicator used } \\
\hline & & $\begin{array}{l}\text { Concentration in } \\
\text { wage setting }\end{array}$ & $\begin{array}{l}\text { Employment } \\
\text { protection } \\
\text { legislation }\end{array}$ & $\begin{array}{l}\text { Product market } \\
\text { regulation }\end{array}$ & $\begin{array}{l}\text { De-trended } \\
\text { product market } \\
\text { regulation }\end{array}$ \\
\hline$\pi_{t-2}^{i}+\gamma_{t}^{i}$ & $0.16^{* * *}(0.03)$ & $0.16^{\star * *}(0.03)$ & $0.16^{\star * \star}(0.03)$ & $0.16^{\star * *}(0.03)$ & $0.17^{\star * *}(0.03)$ \\
\hline$G A P_{t-1}^{+^{i}}$ & $0.29^{\star * \star}(0.07)$ & $0.30^{\star \star \star}(0.07)$ & $0.28^{\star \star \star}(0.06)$ & $0.29^{\star * \star}(0.07)$ & $0.29^{\star * \star}(0.06)$ \\
\hline$G A P^{-i}{ }_{t-1}$ & $0.15^{\star \star \star}(0.04)$ & $0.20^{* * *}(0.04)$ & $0.22^{* \star \star}(0.04)$ & $0.16^{* * *}(0.04)$ & $0.14^{* * *}(0.04)$ \\
\hline$\nabla P O L_{t}^{i} \cdot G A P^{-i}{ }_{t-1}$ & .. & $-0.28^{* \star *}(0.05)$ & $-0.48^{\star * *}(0.10)$ & $0.21^{* *}(0.09)$ & $-0.37^{\star \star *}(0.14)$ \\
\hline$m_{t}^{i}$ & $0.09^{\star \star \star}(0.03)$ & $0.10^{* * *}(0.03)$ & $0.10^{* * *}(0.03)$ & $0.09^{* * *}(0.03)$ & $0.10^{* * *}(0.03)$ \\
\hline$m_{t-1}^{i}$ & $0.05^{\star} \quad(0.03)$ & $0.05^{\star *}(0.03)$ & $0.05^{\star} \quad(0.03)$ & $0.05^{*}(0.03)$ & $0.05^{*}(0.03)$ \\
\hline$b_{t}^{i}$ & $0.20^{*}(0.10)$ & $0.19^{*}(0.10)$ & $0.19^{\star \star}(0.10)$ & $0.19^{*}(0.10)$ & $0.20^{\star *}(0.10)$ \\
\hline$l_{t-2}^{i}$ & $-0.34^{* * *}(0.10)$ & $-0.32^{* \star \star}(0.10)$ & $-0.38^{* * *}(0.13)$ & $-0.31^{* * *}(0.08)$ & $-0.34^{* \star *}(0.10)$ \\
\hline$l_{t-3}^{i}$ & $-0.44^{* * *}(0.10)$ & $-0.43^{\star \star \star}(0.11)$ & $-0.49^{* * *}(0.14)$ & $-0.41^{* * *}(0.09)$ & $-0.44^{\star * *}(0.11)$ \\
\hline$r_{t-1}^{i}$ & $-0.03^{* *}(0.01)$ & $-0.03^{\star * *}(0.01)$ & $-0.03^{\star * \star}(0.01)$ & $-0.03^{*}(0.01)$ & $-0.03^{\star \star *}(0.01)$ \\
\hline Adjusted $R^{2}$ & 0.44 & 0.45 & 0.45 & 0.44 & 0.44 \\
\hline Number of observations & 1360 & 1360 & 1360 & 1360 & 1360 \\
\hline $\begin{array}{ll}\text { Note: } & \\
{ }_{* * *} & \text { Significance at th } \\
* & \text { Significance at th } \\
& \text { Significance at } 10\end{array}$ & $\begin{array}{l}1 \% \text { level. } \\
5 \% \text { level. } \\
\text { level. }\end{array}$ & & & & \\
\hline
\end{tabular}

8. We have also experimented with HP filters to estimate trend output. However, unless very high values of the smoothing parameter $\lambda$ are imposed (in which case the trend approaches a log-linear trend), this filter fails to capture the medium-term (7-10 years) cycle we are focussing on (it rather captures the 2-4 years cycle which is normally associated wit inventory movements). 


\subsection{A vertical long-run Phillips curve}

37. The Philips curve tested in the previous specifications corresponded to the short term theoretical background that presupposes a trade-off between NAIRU/ output gap on the one hand and inflation on the other hand. Yet, it is widely accepted that in the long run no such trade-off exists so that the long run Phillips curve is vertical - that is to say independent of output developments. Although a Wald test rejected the hypothesis that the coefficients on expected inflation summed to unity in Equation (2), regressions have been run where this constraint was imposed. The estimated coefficients on the output gap and its interaction (in the case of negative gaps) with structural indicators proved robust to the imposition of this constraint (see Table 10).

Table 10. Equation with imposed unity on inflation expectations (past and future)

1985Q1 - 2004Q4, standard errors in brackets

\begin{tabular}{|c|c|c|c|c|}
\hline \multirow[t]{2}{*}{ Explanatory variable } & \multirow{2}{*}{$\begin{array}{l}\text { Without structural } \\
\text { policy indicator }\end{array}$} & \multicolumn{3}{|c|}{ Structural policy indicator used } \\
\hline & & $\begin{array}{l}\text { Concentration in wage } \\
\text { setting }\end{array}$ & $\begin{array}{c}\text { Employment protection } \\
\text { legislation }\end{array}$ & $\begin{array}{l}\text { Product market } \\
\text { regulation }\end{array}$ \\
\hline$\pi_{t-2}^{i}+\gamma_{t}^{i}$ & $0.62^{* * *}(0.05)$ & $0.62^{* * *}(0.05)$ & $0.62^{* * *}(0.05)$ & $0.62^{* * *}(0.05)$ \\
\hline$\pi_{t-3}^{i}+\gamma_{t}^{i}$ & 1-above & 1-above & 1-above & 1-above \\
\hline$G A P_{t-1}^{+i}$ & $0.33^{\star *}(0.14)$ & $0.34^{\star \star}(0.13)$ & $0.32^{\star *}(0.13)$ & $0.33^{* *}(0.14)$ \\
\hline$G A P^{-i}{ }_{t-1}$ & $0.27^{\star \star \star}(0.06)$ & $0.32^{* \star *}(0.06)$ & $0.33^{\star \star *}(0.06)$ & $0.30^{* * *}(0.06)$ \\
\hline$\nabla P O L_{t}^{i} \cdot G A P_{t-1}^{-i}$ & & $-0.32^{* \star *}(0.07)$ & $-0.51^{* \star \star}(0.14)$ & $-0.30^{\star \star}(0.13)$ \\
\hline$m_{t}^{i}$ & $0.07^{\star \star}(0.04)$ & $0.08^{\star *}(0.04)$ & $0.08^{* *}(0.04)$ & $0.08^{* *}(0.04)$ \\
\hline$m_{t-1}^{i}$ & $0.05^{\star} \quad(0.03)$ & $0.06^{\star} \quad(0.03)$ & $0.05^{\star} \quad(0.03)$ & $0.06^{\star} \quad(0.03)$ \\
\hline$b_{t}^{i}$ & $0.11 \quad(0.11)$ & $0.10 \quad(0.11)$ & $0.11 \quad(0.11)$ & $0.11 \quad(0.11)$ \\
\hline$l_{t-2}^{i}$ & $-0.23^{*}(0.13)$ & $-0.21 \quad(0.13)$ & $-0.24^{\star *}(0.11)$ & $-0.25^{\star \star}(0.11)$ \\
\hline$l_{t-3}^{i}$ & $-0.31^{* *}(0.13)$ & $-0.29^{\star *}(0.13)$ & $-0.33^{* * *}(0.12)$ & $-0.33^{\star * *}(0.12)$ \\
\hline$r_{t-1}^{i}$ & $0.00 \quad(0.01)$ & $0.00 \quad(0.01)$ & $0.00 \quad(0.01)$ & $0.00 \quad(0.01)$ \\
\hline Adjusted $R^{2}$ & 0.13 & 0.14 & 0.14 & 0.13 \\
\hline Number of observations & 1360 & 1360 & 1360 & 1360 \\
\hline
\end{tabular}




\section{Concluding remarks}

38. Since the downturn in 2001 inflation in the euro area has remained flat at just above the $2 \%$ mark while slack accumulated. In its pursuit of price stability over the medium term, the European Central Bank (ECB) aims to keep inflation close to but below $2 \%$. As recorded inflation has been slightly overshooting this mark, monetary policy has had little leeway to boost the economy out of near-stagnation. An intriguing question is why the euro area features this lack of inflation responsiveness and whether this can be attributed to structural policy settings. If structural policy settings prove key in this regard, pursuing structural reforms as envisaged in the Lisbon strategy would not only boost trend growth, but also raise the speed at which cyclical slack in the euro area is absorbed.

39. The main finding is that more stringent product and labour market institutions are associated with a smaller decline in inflation when output drops below potential than is the case with more flexible institutional settings. More flexible structural settings are therefore desirable in the euro area not only to underpin the goal of lifting potential growth but also for their added benefit of providing more leeway for monetary policy. More flexible structural settings are associated with lower sacrifice ratios for monetary policy since less of an output deceleration is needed to curb inflation. Besides, the data indicates that moving to a lower inflation environment implies higher sacrifice ratios. 


\section{BIBLIOGRAPHY}

Adam, K. and M. Padula (2003), "Inflation dynamics and subjective expectations in the United States", ECB Working Paper, No. 222, Frankfurt.

Akerlof, G., W. Dickens and W. Perry (1996), "The Macro-economics of Low Inflation”, Brookings Papers on Economic Activity.

Akerlof, G., W. Dickens and W. Perry (2000), "Near-rational Wage and Price Setting and the Long-run Phillips Curve", Brookings Papers on Economic Activity.

Andrews, D., and W.K. Chen (1994), "Approximately Median-Unbiased Estimation of Autoregressive Models", Journal of Business and Economic Statistics, Vol. 12.

Angeloni, I., L. Aucremanne, M. Ehrmann, J. Gali, A. Levin and F. Smets (2004), "Inflation Persistence in the Euro Area: Preliminary Summary of Findings", paper presented at the ECB conference on inflation persistence held in Frankfurt on 10-11 December 2004, available at www.ecb.int.

Bårdsen, G., E. Jansen and R. Nymoen (2004), "Econometric Evaluation of the New Keynesian Phillips Curve", Oxford Bulletin of Economics and Statistics, Vol. 66.

Benati, L.(2004), "International Evidence on the Persistence of Inflation", paper based on a presentation to the 2003 North American Summer meetings of the Econometric Society, downloaded from www.ssrn.com.

Ciccarrelli, M. (2004), "Inflation Persistence in the Euro Area - Discussion of aggregate and sectoral results", ECB Conference on Inflation Persistence in the euro area, Frankfurt, 10-11 December 2004, available from http://www.ecb.int/events/pdf/conferences/inflationpersistence.

Cogley, T., and T. J. Sargent (2003) "Drifts and Volatilities: Monetary Policies and Outcomes in the Post-WWII U.S.,” New York University, mimeo, downloaded from ideas.repec.org.

Cotis, J.P., J. Elmeskov and A. Mourougane (2005), "Estimates of Potential Output: Benefits and Pitfalls from a Policy Perspective", in Reichlin, L., ed., The Euro Area Business Cycle: Stylized Facts and Measurement Issues, Centre for Economic Policy Research, London.

CPB Netherlands Bureau for Economic Policy Analysis, (2004), "A Quantitative Assessment for the EU Proposals for an Internal Market for Services", Communication 23 September 2004, The Hague.

Dossche, M. and Everaert, G. (2004), "Measuring Inflation Persistence: a Structural Time Series Approach", ECB Conference on Inflation Persistence in the euro area, Frankfurt, 10-11 December 2004.

Elmeskov, J., J. P. Martin and S. Scarpetta (1998), "Key Lessons for Labour Market Reforms: Evidence from OECD Countries' Experiences”, Swedish Economic Policy Review, Vol. 5.

European Commission (2003), The EU Economy: 2003 Review, Brussels.

Henry, S. and A. Pagan, "The Econometrics of the New Keynesian Policy Model: Introduction", Oxford Bulletin of Economics and Statistics, Vol. 66.

Holden, J. (1994), "Wage Bargaining and Nominal Rigidities", European Economic Review, Vol. 38. 


\section{ECO/WKP(2005)22}

Holden, J. (2004), "The Costs of Price Stability: Downward Nominal Wage Rigidity in Europe", Economica, Vol. 71.

Honohan, P. and P. Lane (2003), "Divergent Inflation in EMU”, Economic Policy, Vol. 37.

Honohan, P. and P. Lane (2004), "Exchange Rates and Inflation under EMU: an Update", CEPR Discussion Paper Series, No. 4583.

Issing, O. (2004), Address to the ECB conference on inflation persistence in the euro area, Frankfurt am Main, 10 December 2004, downloaded from www.ecb.int on 20 Dec 2004.

Krugman, P. and M. Obstfeld (1994), International Economics, Harper Collins, New York.

Levin, A. and J. Piger (2003), "Is Inflation Persistence Intrinsic in Industrial Economies?", Working Papers of the Federal Reserve Bank of St. Louis, No. 2002-023.

Mankiw, G. and R. Reis (2002), "Sticky Information versus Sticky Prices: a Proposal to Replace the New Keynesian Phillips Curve”, Quarterly Journal of Economics, Vol. 117, No. 4.

Marques, C. R. (2004), “Inflation Persistence: Facts or Artefacts”, ECB Working Paper Series, No. 371, Frankfurt.

Mayes, D. and M. Viren (2002), "Asymmetry and the Problem of Aggregation in the Euro Area", Empirica, Vol. 29.

McAdam, P. and A. Willman (2004), "Supply, Factor Shares and Inflation Persistence: Re-Examining Euro Area New Keynesian Phillips Curves", Oxford Bulletin of Economics and Statistics, Vol. 66.

Mehra, Y. (2004), “The Output Gap, Expected Future Inflation and Inflation Dynamics: Another Look", Topics in Macroeconomics, Vol. 4 Issue 1.

Mishkin, F. (1990), “The Information in the Longer Maturity Term Structure About Future Inflation", Quarterly Journal of Economics, Vol. 105, No. 3.

Mourougane, A. and H. Ibaragi (2004), "Is there a Change in the Trade-Off Between Output and Inflation at Low or Stable Inflation Rates? Some Evidence in the Case of Japan", OECD Economics Department Working Papers, No. 379.

Nicoletti, G. and S. Scarpetta (2003), "Regulation, Productivity and Growth: OECD Evidence", OECD Economics Department Working Papers, No. 347, OECD, Paris.

Nunziata, L. and C. Bowdler (2005), "Inflation Adjustment and Labour Market Structures: Evidence from a Multi-Country Study", IZA Discussion Paper, No. 1510, Bonn.

OECD (2005a), Economic Policy Reforms: Going for Growth, Paris.

OECD (2005b), OECD Economic Surveys: Euro Area, Paris.

O’Reilly, G. and K. Whelan (2003), "Has Euro Area Inflation Persistence Changed over Time?", ECB Working Paper Series, No. 335. 
Perron, P. (1989), “The Great Crash, the Oil Price Shock and the Unit Root Hypothesis", Econometrica, Vol. 57.

Paloviita, M. (2004), "Inflation Dynamics in the Euro Area and the Role of Expectations: Further Results", Bank of Finland Discussion Paper, No. 21, Helsinki.

Tobin, J. (1972), “Inflation and Unemployment”, American Economic Review, Vol. 69.

Vogt, L. (2005), “The EU's Internal Market: At Your Service?", OECD Economics Department Working Papers, forthcoming.

White, H. (1980), “A Heteroscedasticity-Consistent Covariance Matrix Estimator and a Direct Test for Heteroscedasticity", Econometrica, Vol. 48. 


\section{WORKING PAPERS}

The full series of Economics Department Working Papers can be consulted at www.oecd.org/eco/Working_Papers/

434.. Measuring Cyclically-Adjusted Budget Balances for OECD Countries (July 2005) Nathalie Girouard and Christophe André

433. Product Market Competition and Economic Performance in the United Kingdom (June 2005) Maria Maher and Michael Wise

432. The Benefits of Liberalising Product Markets and Reducing Barriers to International Trade and Investment: the Case of the United States and the European Union (May 2005)

431. Boosting Growth through Greater Competition in Denmark (May 2005) Martin Jørgensen

430. Fifteen Years of Economic Reform in Russia: What Has Been Achieved: What Remains to be Done? (May 2005) Rudiger Ahrend and William Tompson

429. Assessing the OECD Job Strategy: Past Developments and Reforms (May 2005) Nicola Brandt, Jean-Marc Burniaux and Romain Duval

428. Ageing, Welfare Services and Municipalities in Finland (May 2005) Jens Lundsgaard

427. The Impact of Structural Policies on Trade-Related Adjustment and the Shift to Services (April 2005) Per Mathis Kongsrud and Isabelle Wanner

426. Product Market Competition and Economic Performance in Iceland (April 2005) Thomas Laubach and Michael Wise

425. Enhancing Brazil's Regulatory Framework for Network Industries: The Case of Electricity, Oil and Gas, and Water and Sanitation (April 2005) Edmar Almeida and Nanno Mulder

424. Education Attainment in Brazil: The Experience of FUNDEF (April 2005) Luiz de Mello and Mombert Hoppe

423. Estimating a Fiscal Reaction Function: The Case of Debt Sustainability in Brazil (April 2005) Luiz de Mello

422. Product Market Competition and Economic Performance in the Netherlands (April 2005) Maria Maher and Michael Wise

421. Product Market Competition and Economic Performance in Canada (April 2005) Maria Maher and Jay Shaffer

420. The Impact of Ageing on Demand, Factor Markets and Growth (April 2005) Joaquim Oliveira Martins, Frédéric Gonand, Pablo Antolin, Christine de la Maisonneuve and Kwang-Yeol Yoo.

419. Product Market Regulation in OECD Countries: 1998 to 2003

(February 2005) Paul Conway, Véronique Janod and Giuseppe Nicoletti

418. Reforming Turkey's Public Expenditure Management 
(February 2005) Rauf Gönenç, Willi Leibfritz and Erdal Yilmaz

417. Fiscal Gimmickry in Europe: One-Off Measures and Creative Accounting

(February 2005) Vincent Koen and Paul van den Noord

416. Getting the Most out of Public Sector Decentralisation in Japan

(January 2005) Isabelle Joumard and Tadashi Yokoyama

415. Structural Policy Reforms and External Imbalances

(January 2005) Mike Kennedy and Torsten Sløk

414. The Jobs Challenge in Poland: Policies to Raise Employment (January 2005) Andrew Burns and Przemyslaw Kowalski

413. Product Market Competition and Economic Performance in Finland (December 2004) Jens Høj and Michael Wise

412. Oil Price Developments: Drivers, Economic Consequences and Policy Responses

(December 2004) Anne-Marie Brook, Robert Price, Douglas Sutherland, Niels Westerlund and

Christophe André

411. Wealth Effects on Money Demand in EMU: Econometric Evidence

(November 2004) Laurence Boone, Fanny Mikol and Paul van den Noord

410. Banking Reform in Russia : Problems and Prospects

(November 2004) William Tompson

409. Public Expenditure in France

(November 2004) Andrew Burns and Alessandro Goglio

409 La gestion des dépenses publiques en France

(Novembre 2004) Andrew Burns et Alessandro Goglio

408. Russian Industrial Restructuring: Trends in Productivity, Competitiveness and Comparative Advantage (October 2004) Rudiger Ahrend

407. Improving the Capacity to Innovate in Germany

(October 2004) Andrés Fuentes, Eckhard Wurzel and Margaret Morgan

406. Tax Treatment of Private Pension Savings in OECD Countries and the Net Tax Cost per Unit of Contribution to Tax-Favoured Schemes

(October 2004) Kwang-Yeol Yoo and Alain de Serres

405. The Reform of the Health Care System in Portugal

(October 2004) Stéphanie Guichard

404. Accounting for Russia's Post-Crisis Growth

(October 2004) Rudiger Ahrend

403. Restructuring Russia's Electricity Sector: Towards Effective Competition or Faux Liberalisation? (October 2004) William Tompson

402. Russia's Gas Sector: The Endless Wait for Reform?

(September 2004) Rudiger Ahrend and William Tompson

401. One Money, One Cycle? Making Monetary Union a Smoother Ride

(September 2004) Peter Hoeller, Claude Giorno and Christine de la Maisonneuve 